\title{
Determining the Thermodynamic Parameters of Iron Oxide Leaching from a Nigerian Clay
}

\author{
Orugba Oghenero Henry ${ }^{1}$ \& Iweka Chukwuka Sunday ${ }^{2}$ \\ ${ }^{1}$ Department of Chemical Engineering Technology \\ 2Department of Mechanical Engineering Technology \\ Delta State Polytechnic, Ozoro Nigeria \\ E-mail: orugbahenry@yahoo.com; chukaiweka@yahoo.com
}

\begin{abstract}
In this research, the viability of Ozoro clay and the kinetics of its dissolution in tetraoxosulphate (vi) acid has been studied. The XRF analysis carried out revealed that the local clay has $12.00 \%$ of iron oxide making it a viable raw material for the production of iron. From the heat activation process, a temperature of $800^{\circ} \mathrm{C}$ for a period of $1 \mathrm{hr}$ was discovered to be the best calcinations condition for the clay. From the process parameter study, it was found that dissolution rate of iron increased with leaching temperature, acid concentration, liquid-solid ratio and stirring speed while a decrease in iron yield was observed with increase in particle size of clay. On testing the data with the different forms of the shrinking core model, the product layer diffusion model gave the best fit and the equation generated was $1+2(1-\mathrm{X})-3(1-\mathrm{X})^{\frac{2}{3}}=$ $0.0008697 \mathrm{C}_{\mathrm{H} 2 \mathrm{SO} 4}^{0.608} \mathrm{D}^{-0.5937}(\mathrm{~L})^{1.19} \mathrm{~S}^{0.6409} \exp \left(\frac{-38.88}{\mathrm{RT}}\right) \mathrm{t}$. The activation energy was calculated to be $38.88 \mathrm{KJ} / \mathrm{Mol}$.
\end{abstract}

Key words: Clay, Leaching, Iron Oxide, Sulphuric Acid and Calcinations

Aims Research Journal Reference Format:

Ukume, G.D., Jude, W.I. \& Uguma, V.U. (2019): Determining the Thermodynamic Parameters of Iron Oxide Leaching

from a Nigerian Clay. Advances in Multidisciplinary Research Journal. Vol. 5. No. 1, Pp 83-96.

Article DOI: dx.doi.org/10.22624/AIMS/V5N1P9

Available online at www.aimsjournal.net

\section{INTRODUCTION}

Iron is usually produced from the hematite ore. The ever increasing demand for this ore has made it unaffordable for those countries that have little or no deposits of the ore. Several researches have been carried out to obtain alternative raw materials. Several types of clay have been found to contain considerable amount of iron in form of oxides. The results from the work of some researchers have proven most Nigerian clays to be considerably rich in iron (Alafara et al, 2005; Ogbuago et al, 2007; Lori et al, 2007; Ogbemudia et al, 2010 and Ajemba and Onukwuli, 2012). However, it is worthy of note that the extent of the dissolution reaction depends on both clay mineral type and reaction conditions, such as the clay- toacid ratio, acid concentration, time and temperature of the reaction (Vicente et al, 1994). Panias et al, (1999) investigated the mechanism of iron oxide dissolution in aqueous oxalic acid. Ambikadevi and Lalithambika, (2000) tested the efficiencies of different kinds of organic acids in leaching iron oxide from clay and found that oxalic acid was the most efficient. Sultana et al, (2014) have also investigated the leaching of iron oxide from clay in oxalic acid and hydrochloric acid. According to Sultana et al. (2014), the shrinking core model and the progressive conversion model are the two simple models generally considered for the non-catalytic reaction of particles with the surrounding fluids and the shrinking core model is preferred for spherical particle reaction kinetics. 
Of the many different forms of the shrinking core model, the liquid film controlled model, the product layer controlled model and the chemical reaction controlled model have been identified to be the three most suitable for preliminary selection of the kinetic models (Ajemba and Onukwuli, 2012 and Sultana et al, 2014). The result of the leaching experiments is matched with a kinetic model and data from the selected model is used to determine the activation energy. The aim of this research work is to evaluate the effectiveness of the local clay in iron oxide production and identify the reaction mechanism in order to obtain the activation energy.

\section{EXPERIMENTAL}

\subsection{Sample preparation}

The local clay used in this work was obtained from Ozoro $\left(6.24^{\circ} \mathrm{N}, 5.55^{\circ} \mathrm{E}\right)$ in Delta State Nigeria. The clay was soaked in water for two days to ease the removal of debris using the method of filtration. The clay was sun-dried for 24 hours then oven dried at $60^{\circ} \mathrm{C}$ for 18 hours to aggregate the particles.

\subsection{Activation procedure}

Though heat activation enhances the release of iron from clays, temperature and period of calcinations are key factors that must be known. In order to determine the best calcinations temperature and period of calcinations, the samples were subjected to heat treatment in a muffle furnace (model LMF-3550/120V) at different periods. The temperatures considered were $400^{\circ} \mathrm{C}, 500^{\circ} \mathrm{C}, 600^{\circ} \mathrm{C}, 700^{\circ} \mathrm{C}, 800^{\circ} \mathrm{C}$ and $900^{\circ} \mathrm{C}$ at different periods of $30 \mathrm{~min}, 60 \mathrm{~min}, 120 \mathrm{~min}$ and 180 making a total of 24 activated samples. The samples were all ground to the same particle size of $0.045 \mathrm{~mm}$ and properly labeled and were subjected to the same leaching conditions.

\subsection{Characterization}

The clay was characterized using the X-ray fluorescence XRF (Model Lab-X3500) to determine the chemical composition of the clay minerals. The morphology of the clay was determined with the Scanning Electron Microscope, SEM (Model S-3700N). The iron ion content in the leached solution was analyzed with MS- Atomic Absorption Spectrophotometer (AAS).

\subsection{Leaching experiment of the kinetic studies}

$20 \mathrm{~g}$ of the activated clay was weighed into an already determined volume of the acid and heated in a reflux system using a magnetic stirrer (Model CTH 6500). At intervals of 15 minutes, a pipette was used to withdraw $2 \mathrm{ml}$ of the leaching solution from the round bottom flask. The collected sample of leach liquor was allowed to cool on standing for 20 minutes and after which, it was filtered and used for iron estimation using the AAS. The dissolution percentage of the iron in the slurry was calculated according to Orugba et al (2014) as follows:

$$
\mathrm{x}=\frac{\text { amount of } \mathrm{Fe}^{2+} \text { in withdrawn sample }}{\text { total amount of } \mathrm{Fe}^{2+} \text { in withdrawn sample }} \times 100 \%
$$

Where $\mathrm{x}$ represents the percentage of iron leached.

Experiments were performed using the activated sample to investigate the effects of the following variables on the leaching process:

Table 1. Levels of variation of the process variables.

\begin{tabular}{|c|c|c|c|c|}
\hline Parameter & \multicolumn{4}{|c|}{ Levels of variation } \\
\hline Particle size $(\mathrm{mm})$ & 0.054 & 0.105 & 0.25 & 0.54 \\
\hline Acid concentration $\left(\mathrm{Mol} / \mathrm{cm}^{3}\right)$ & 0.5 & 1.5 & 2.0 & 3.0 \\
\hline Liquid-solid ratio $\left(\mathrm{cm}^{3} / \mathrm{g}\right)$ & 4 & 8 & 10 & 16 \\
\hline Stirring speed $(\mathrm{rpm})$ & 90 & 360 & 540 & 720 \\
\hline Leaching temperature $\left({ }^{\circ} \mathrm{C}\right)$ & 45 & 65 & 85 & 95 \\
\hline
\end{tabular}




\section{RESULTS AND DISCUSSION}

\subsection{Results of the characterization}

The XRF analysis presented in Table 2.0 revealed that the clay is rich in silica $\left(\mathrm{SiO}_{2}\right)$, alumina $\left(\mathrm{Al}_{2} \mathrm{O}_{3}\right)$ and iron oxide $\left(\mathrm{Fe}_{2} \mathrm{O}_{3}\right)$ with the percentages of $41.8 \%, 33.90 \%$ and $12.00 \%$ respectively. Copper, nickel and manganese oxides are present in traces.

The result of SEM for the raw and activated clay samples (Figures 1.0 and 2.0) revealed that the pores appeared to open more after the activation process.

Table2: The XRF results of the raw clay sample.

\begin{tabular}{|c|c|}
\hline Chemical composition & \% composition \\
\hline $\mathrm{Al}_{2} \mathrm{O}_{3}$ & 33.90 \\
\hline $\mathrm{SiO}_{2}$ & 41.80 \\
\hline $\mathrm{Fe}_{2} \mathrm{O}_{3}$ & 12.00 \\
\hline $\mathrm{CaO}$ & 0.45 \\
\hline $\mathrm{MnO}$ & 0.08 \\
\hline $\mathrm{K}_{2} \mathrm{O}$ & 5.15 \\
\hline $\mathrm{Ga}_{2} \mathrm{O}_{3}$ & 0.01 \\
\hline $\mathrm{TiO} 2$ & 2.00 \\
\hline $\mathrm{Cr} 2 \mathrm{O} 3$ & 0.16 \\
\hline $\mathrm{V} 2 \mathrm{O} 5$ & 0.10 \\
\hline $\mathrm{NiO}$ & 0.21 \\
\hline $\mathrm{CuO}$ & 0.17 \\
\hline $\mathrm{Rh} 2 \mathrm{O}$ & 3.10 \\
\hline
\end{tabular}

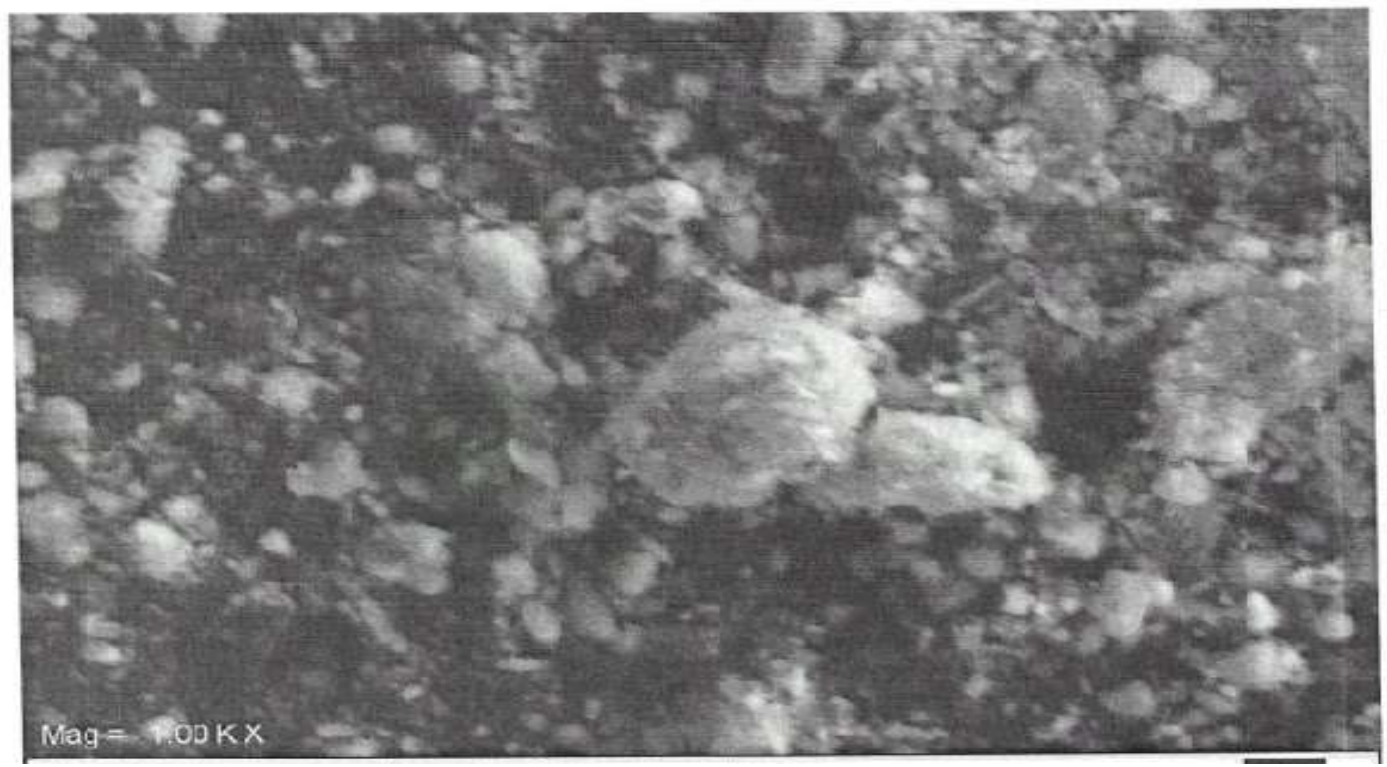

Figure 1: SEM result of the raw clay 


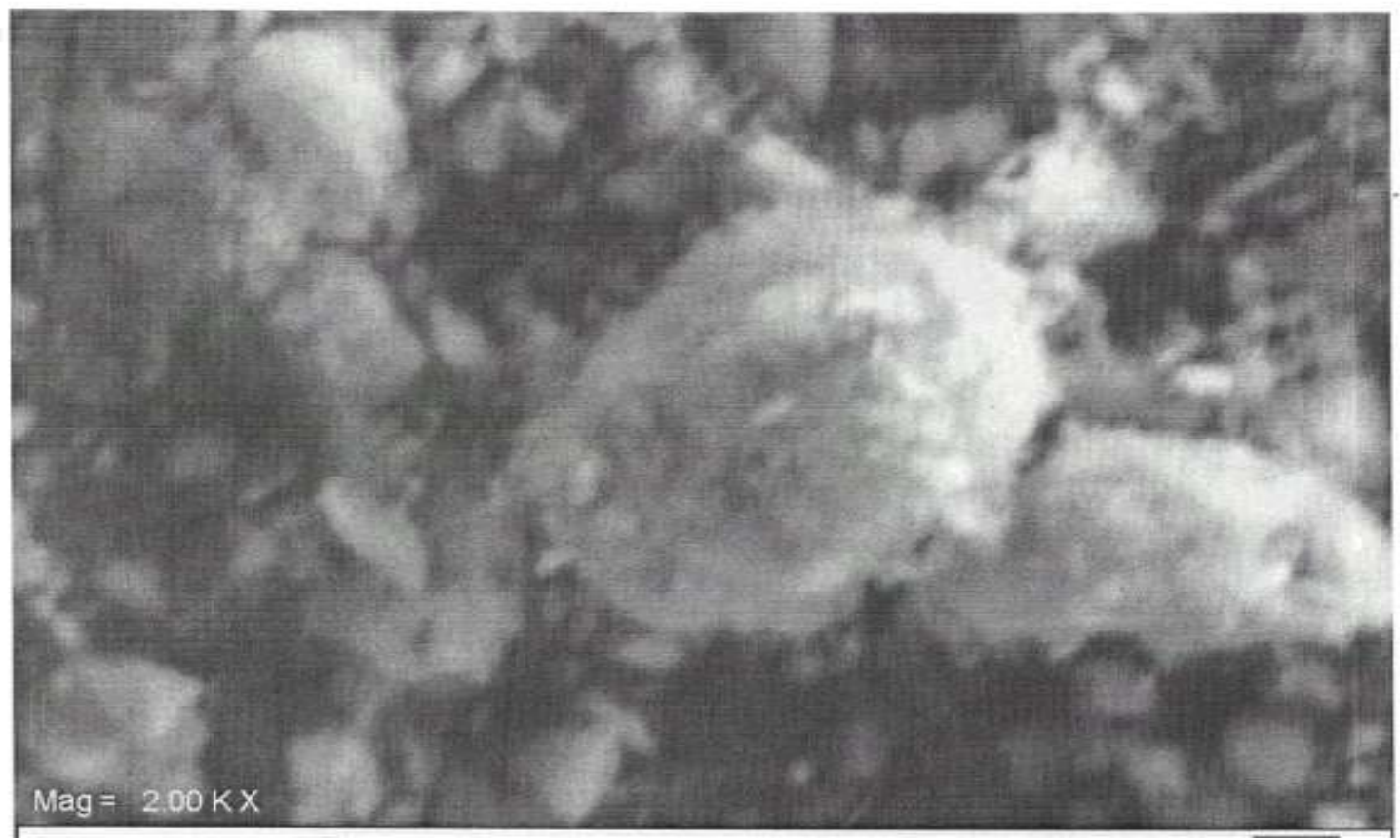

Figure 2.0 SEM result of the activated clay

\subsection{Effect of temperature and period of calcinations on iron yield}

The effect of temperature and period of calcinations on iron yield is presented in Figure 3.0. At lower temperatures (around 400 and $500^{\circ} \mathrm{C}$ ), the leaching rate was low and as the temperature rises, the rate of dissolution of iron also increased until after $800^{\circ} \mathrm{C}$, a decrease was observed. On the influence of time, between $30 \mathrm{~min}$ to one hour, there was a general increase in dissolution rate. After 1 hour, the rate was generally observed to decline except for the temperature of $500^{\circ} \mathrm{C}$ that showed a progressive increase as time was increased. The optimum calcinations condition was found to be $800^{\circ} \mathrm{C}$ at $1 \mathrm{hr}$.

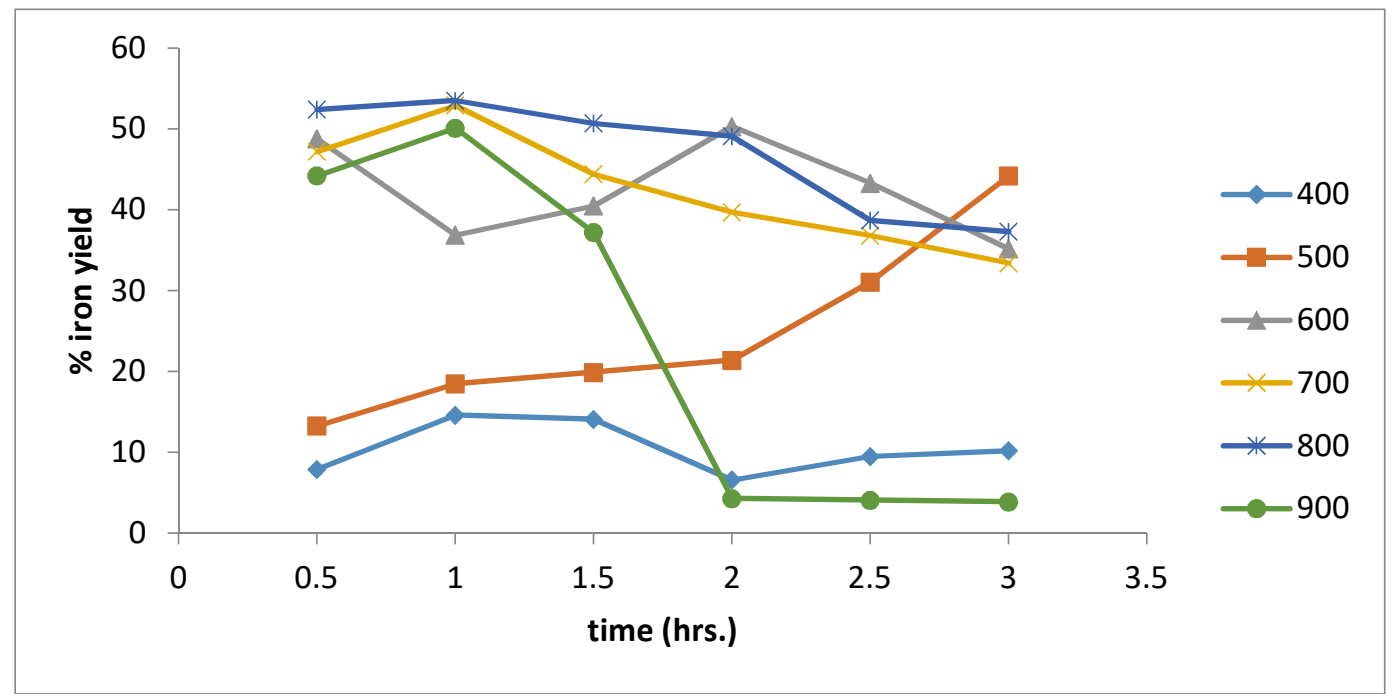

Figure 3.0: Effect of temperature and time of calcinations on iron yield 


\section{EFFECTS OF DISSOLUTION PARAMETERS}

The various process parameters that affect the yield of iron from the clay were investigated to study the reaction mechanism and kinetics. These process parameters include particle size of clay, acid concentration, stirring speed, acid-clay weight ratio and leaching temperature.

\subsection{Effect of particle size and time on iron yield}

Keeping the other parameters constant, the different particle sizes of $0.045 .105,0.25$ and $0.54 \mathrm{~mm}$ were used to study the effect of particle size and time on the yield of iron from the clay and the result is shown in Figure 4.0. It could be seen that as the particle size of clay increased, the iron yield decreased with the highest yield at $0.045 \mathrm{~mm}$. The rate of leaching decreased with time as the graphs appeared flatter with increase period.

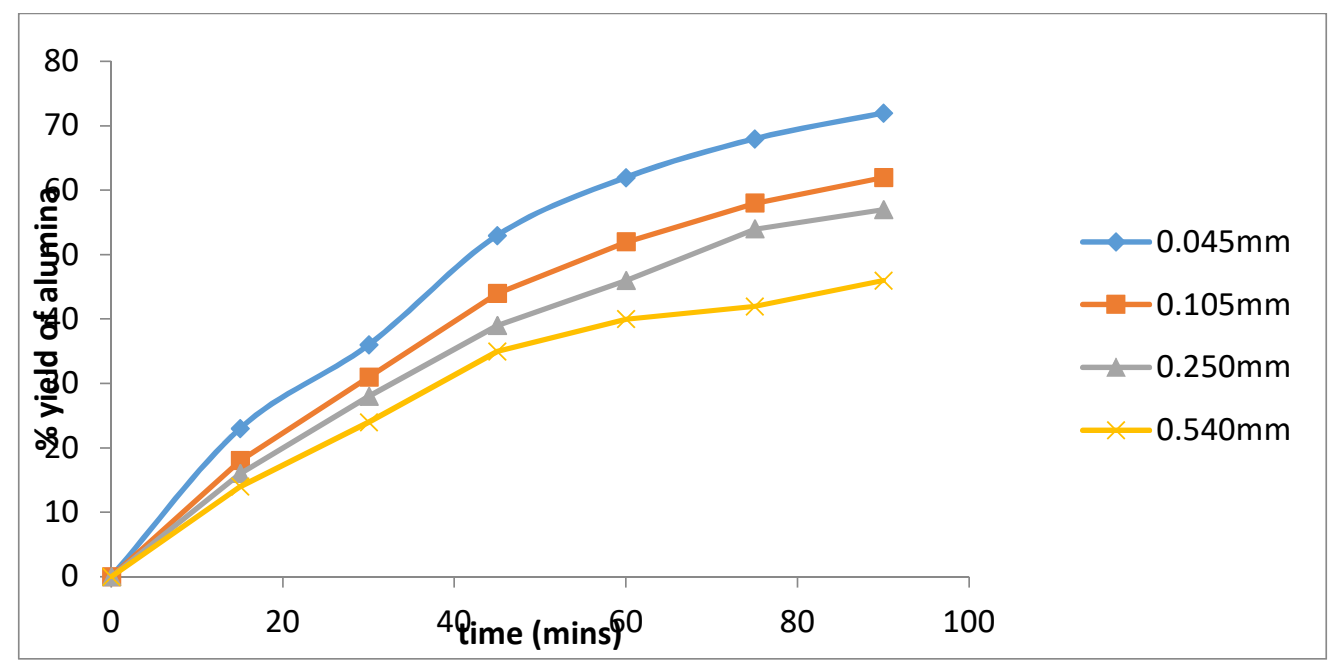

Figure 4.0: Effect of particle size of clay on iron yield

\subsection{Effect of acid concentration and time on iron yield}

The particle size that gave the best yield was used to study the effect of acid concentration on iron yield keeping the remaining parameters constant. The concentrations used were $0.5,1.5,2$ and $3 \mathrm{M}$. From the experimental result on the effect of acid concentration on iron yield shown in Figure 5.0, it could be seen that as the acid concentration increased, the iron yield increased with the maximum yield recorded at the highest concentration of $3.0 \mathrm{M}$. Increase in concentration increased the amount of hydrogen ion in the leaching liquor which enhanced the leaching efficiency.

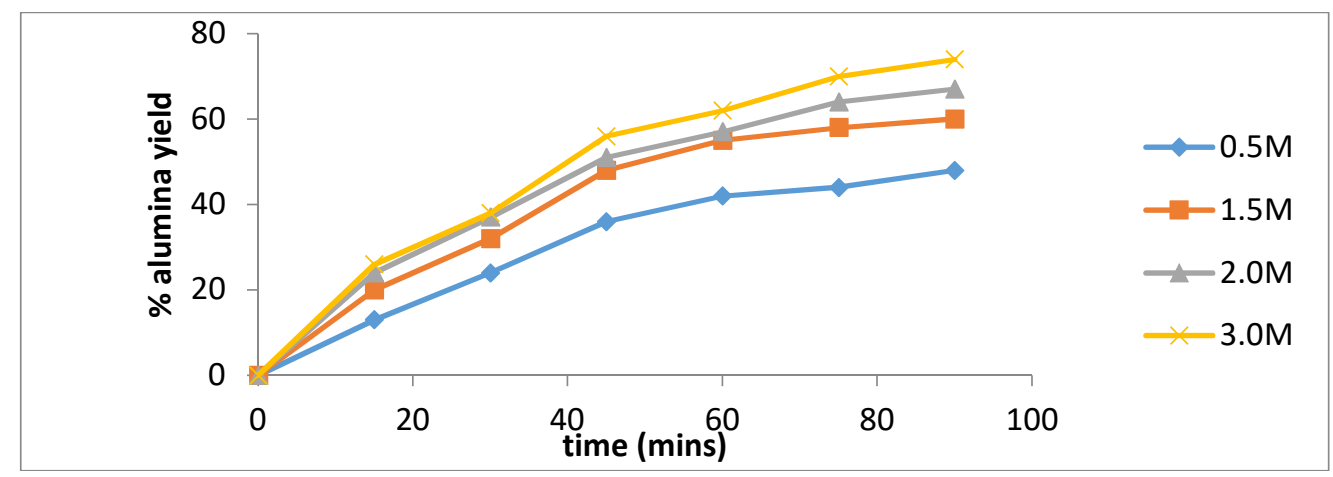

Figure 5.0: Effect of acid concentration on iron yield 


\subsection{Effect of acid-clay ratio and time on iron yield}

Keeping stirring speed and leaching temperature constant and with the particle size and acid concentration that gave the highest yield, the effect of acid-clay ratio on iron yield was studied using ratios of $4,8,10$ and $16 \mathrm{~cm}^{3} / \mathrm{g}$. The result shown in Figure 6.0, revealed that the yield of iron increased as the ratio increased. This is due to the fact that as ratio increases, more fluid is made available to wash off iron ions from the clay.

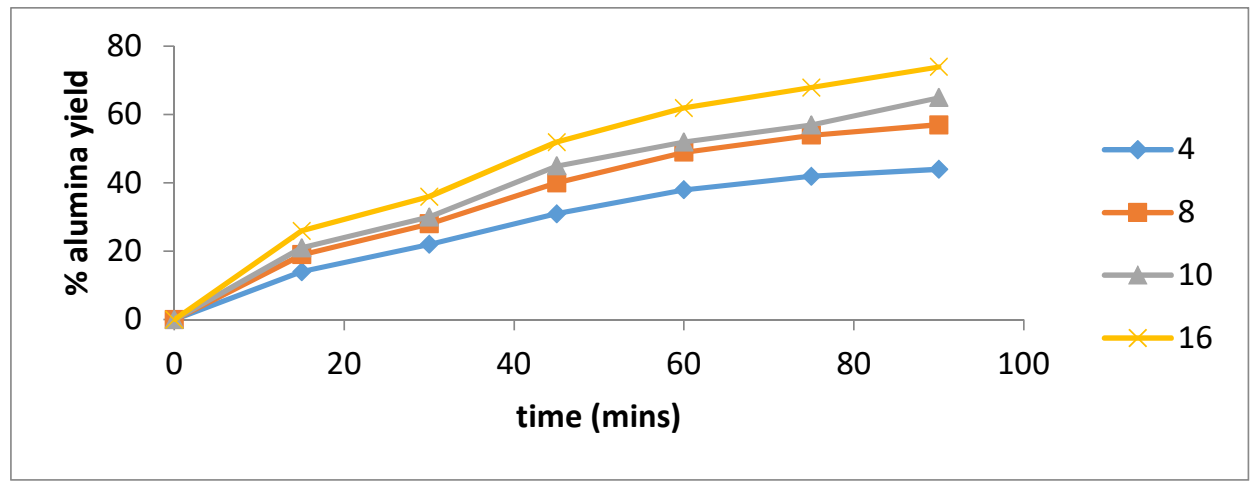

Figure 6.0: Effect of acid-clay ratio on iron yield

\subsection{Effect of stirring speed and time on iron yield}

The particle size of $0.045 \mathrm{~mm}$, acid concentration of $3.0 \mathrm{M}$, acid-clay ratio of 16 and a constant temperature of $65^{\circ} \mathrm{C}$ were maintained while varying the speed at $90,360,540$ and $720 \mathrm{rpm}$ The experimental result of the effect of stirring speed on iron yield is shown in Figure 7.0. The yield of iron appeared to increase with increased stirring speed since stirring makes it possible for the surfaces of the solids to be opened more for proper contact with the fluid. Maximum yield was obtained at 720rpm.

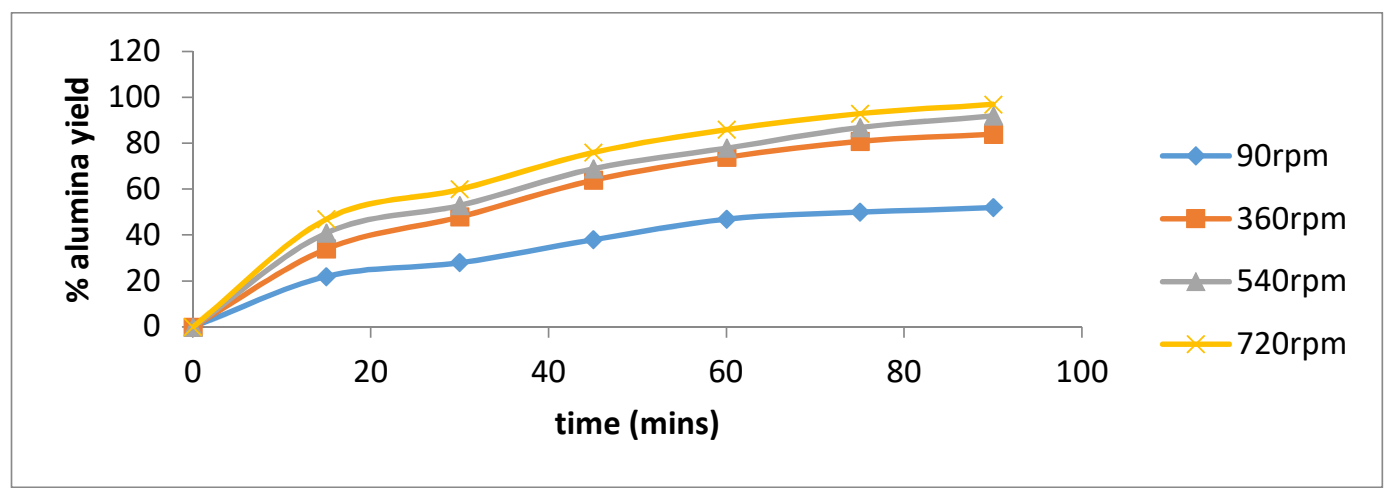

Figure 7.0: Effect of stirring speed on iron yield

\subsection{Effect of temperature and time on iron yield}

To determine the effect of leaching temperature and time on the yield of iron, $0.045 \mathrm{~mm}$ particle size, $3 \mathrm{M}$ acid concentration, $16 \mathrm{~cm}^{3} / \mathrm{g}$ acid-clay ratio and 720rp stirring speed were used while varying the temperature at 45,65 and $85^{\circ} \mathrm{C}$. Experimental result on effect of leaching temperature on iron yield (Figure 8 ) revealed that as leaching temperature increased, the amount of iron dissolved in the solution increased and the highest yield was achieved at the highest temperature of $85^{\circ} \mathrm{C}$. 


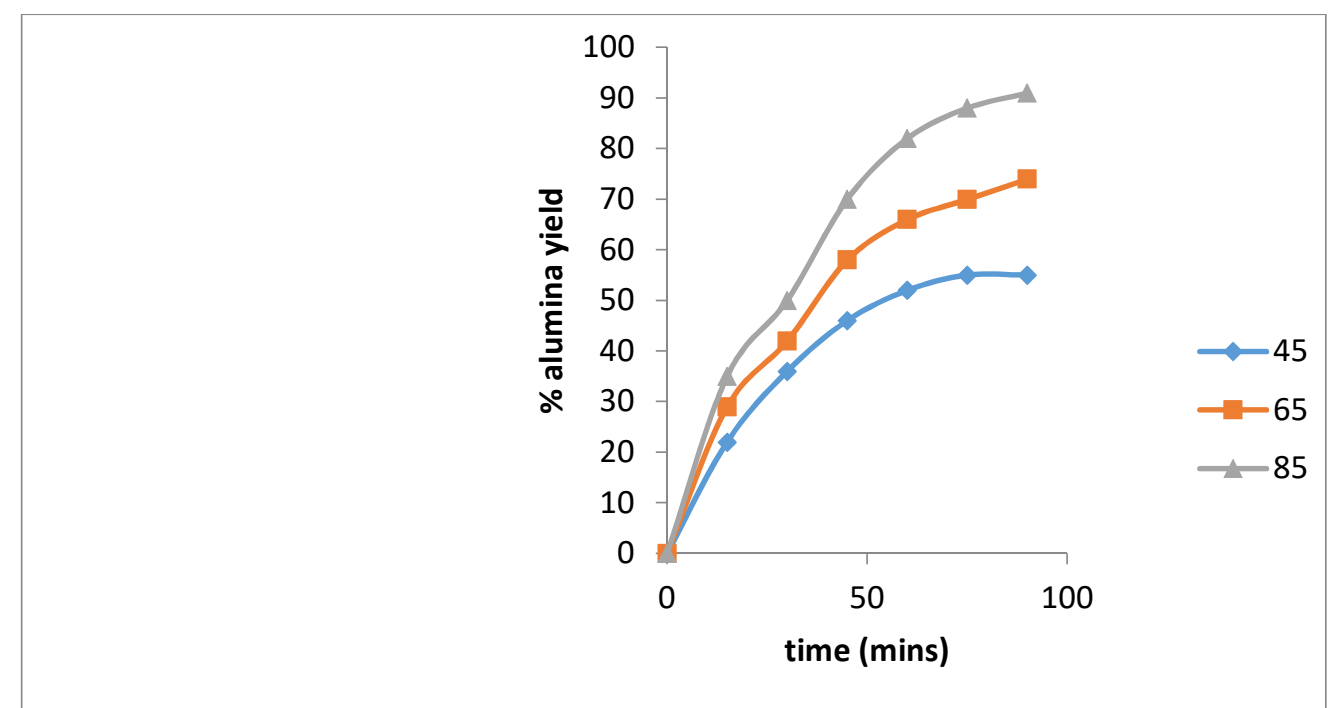

Figure 8.0: Effect of leaching temperature on iron yield

\section{KINETIC STUDIES}

In the kinetics studies, the different forms of the shrinking core model were observed to fit the experimental data obtained in order to identify the reaction mechanism for comparative analysis of the leaching kinetics of iron from the clay with sulphuric acid. The various forms of the shrinking core model are as follows:

chemical reaction controlled model $1-(1-\mathrm{X})^{1 / 3}=$

liquid film diffusion controlled model $1-(1-\mathrm{X})^{2 / 3}=\mathrm{kt}$

product layer diffusion controlled model $1+2(1-\mathrm{X})-3(1-\mathrm{X})^{\frac{2}{3}}=\mathrm{kt}$

Avremi model $-\ln (1-\mathrm{X})=\mathrm{K}_{\mathrm{A}} \mathrm{t}^{\mathrm{m}}$

first order pseudo - homogenous model $-\ln (1-\mathrm{X})=\mathrm{kt}$

Ginstling and Brounshtein model $1-\frac{2}{3}(\mathrm{X})-(1-\mathrm{X})^{\frac{2}{3}}=\mathrm{kt}$

Each of the six kinetic models was applied to test the experimental data already plotted in Figures 4.0, 5.0, $6.0,7.0$ and 8.0 in order to determine the rate controlling mechanism. The resulting graphs are shown in Figures 9.0 through 13.0. The correlation coefficients were used as creteria to measure the fitness of the models to the experimental data. In all the processes, the product layer diffusion controlled process gave the best fits and their values were presented in Table 3.0. 


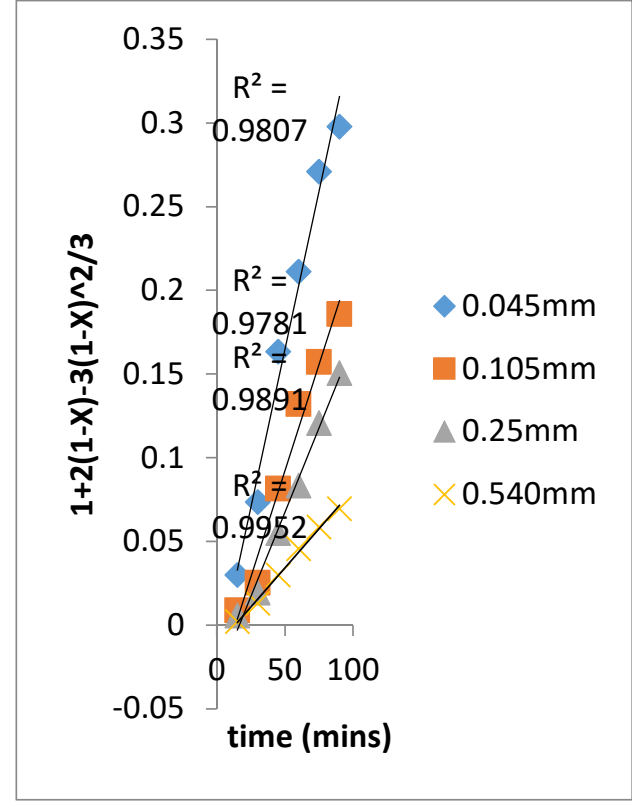

Figure 9.0: Plot of 1+ 2(1-X)-3(1$X)^{\wedge} 2 / 3$ Vs time at different part size for iron with $\mathrm{H}_{2} \mathrm{SO}_{4}$

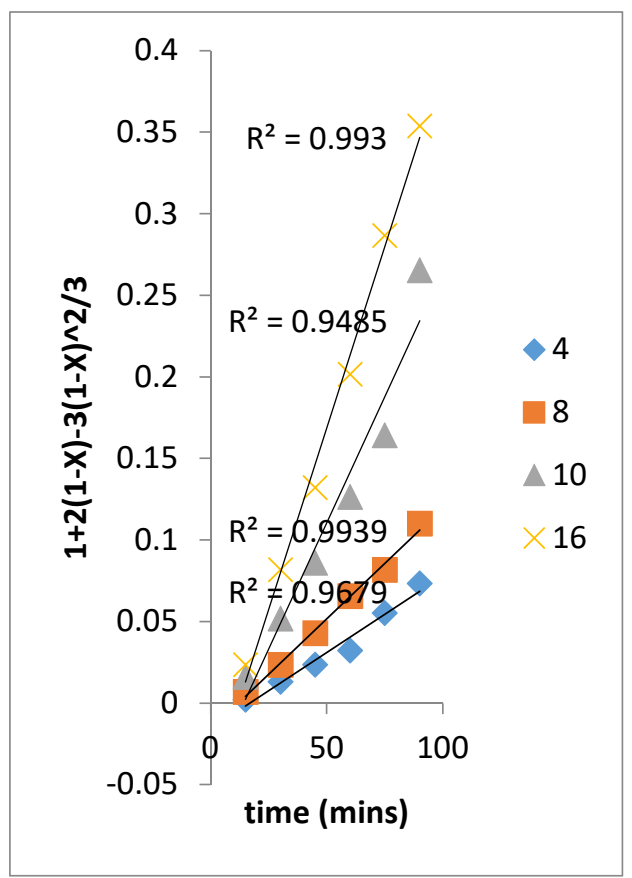

Figure11.0: Plot of 1+ 2(1-X)-3(1$X)^{\wedge} 2 / 3$ Vs time at different liquidsolid ratio for iron with $\mathrm{H}_{2} \mathrm{SO}_{4}$

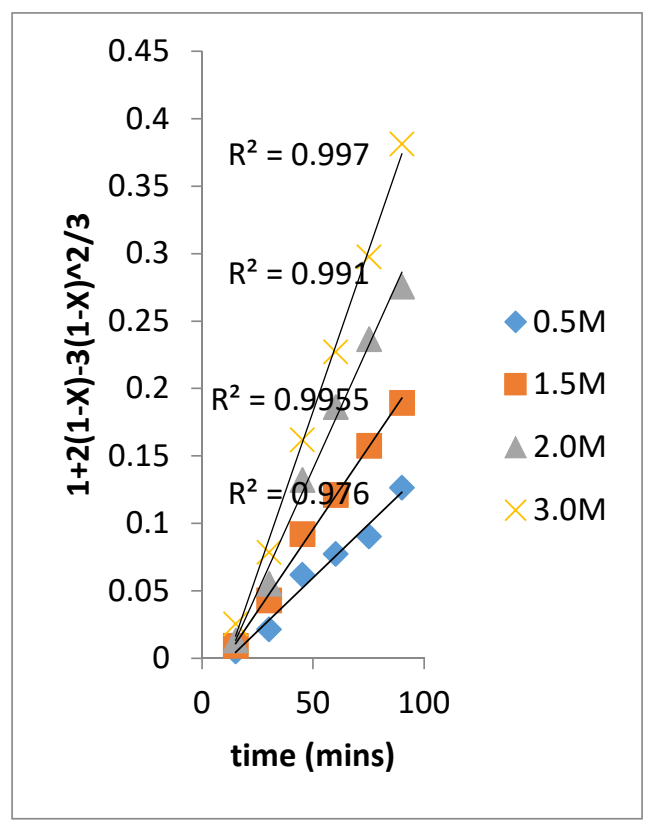

Figure10.0: Plot of 1+ 2(1-X)-3(1$\mathrm{X})^{\wedge} 2 / 3 \mathrm{Vs}$ time at different $\mathrm{H}_{2} \mathrm{SO}_{4}$ Conc for iron

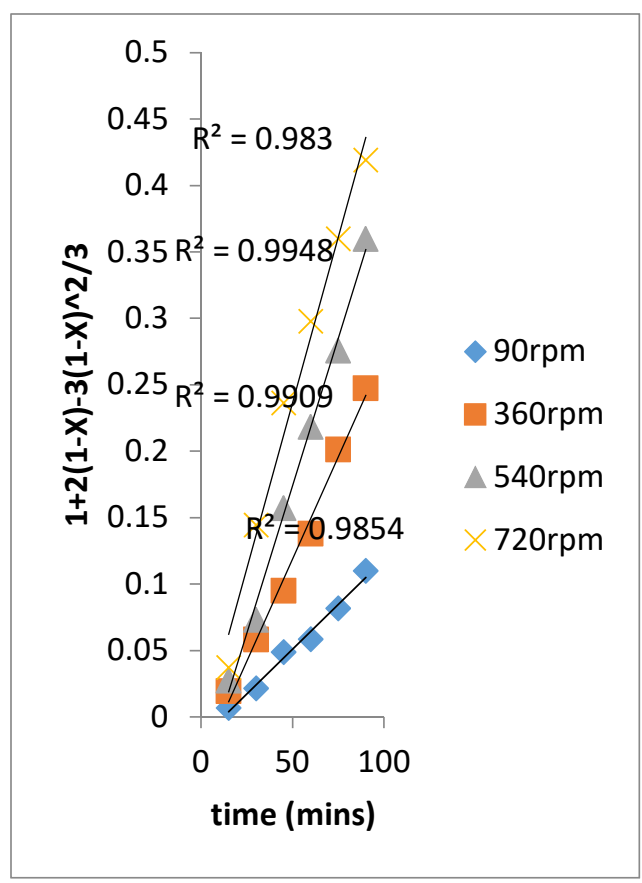

Figure 12.0: Plot of 1+ 2(1-X)-3(1$\mathrm{X})^{\wedge}$ 2/3 Vs time at different stirring speed for iron yield with $\mathrm{H} 2 \mathrm{O} 4$ 


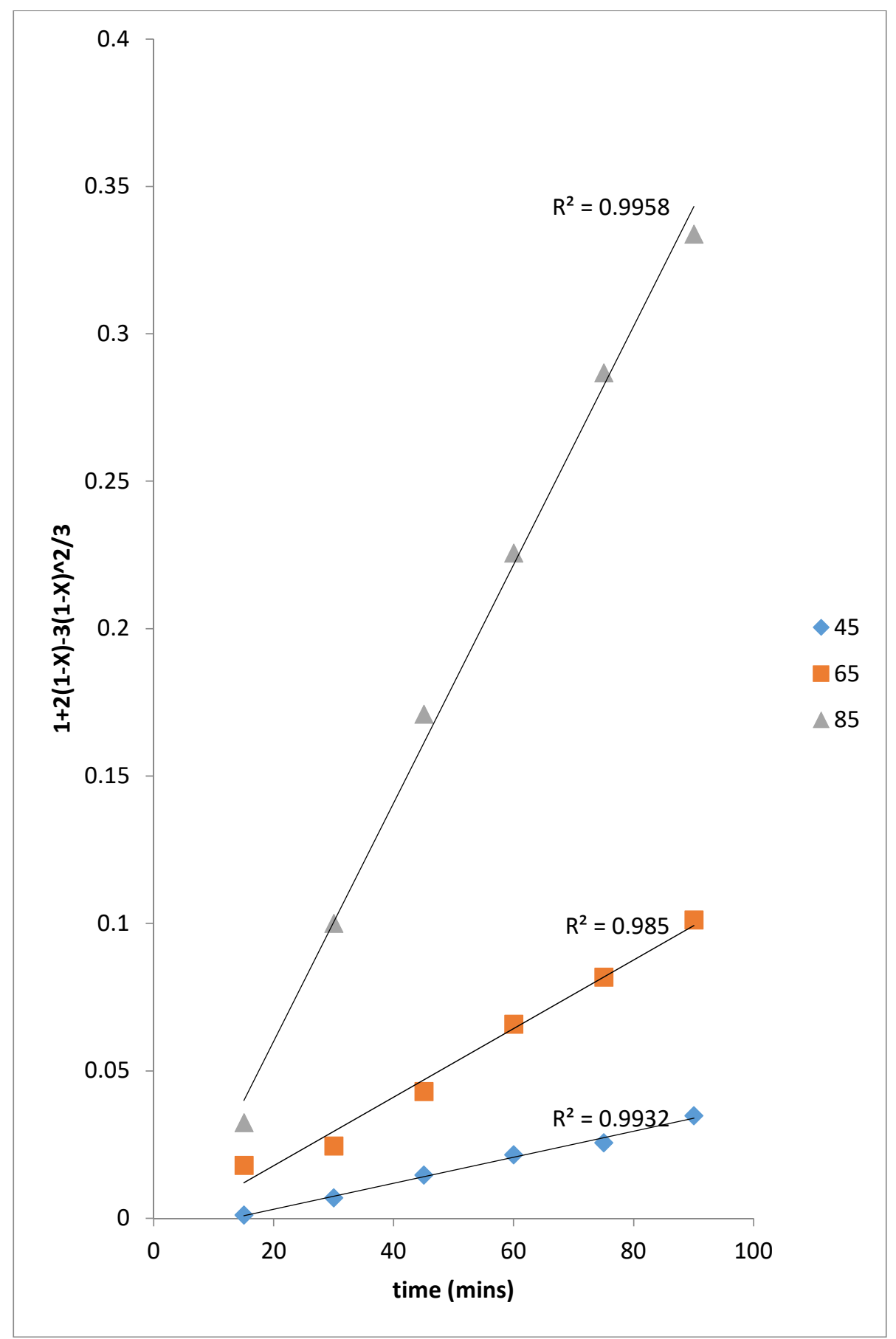

Figure 13.0: Plot of 1+ 2(1-X)-3(1-

$X)^{\wedge} 2 / 3$ Vs time at different temperature for iron with $\mathrm{H}_{2} \mathrm{SO}_{4}$ 
Table 3. Correlation coefficients of the process variables for the different shrinking core models

\begin{tabular}{|c|c|c|c|c|c|}
\hline \multirow{3}{*}{$\begin{array}{l}\text { Process } \\
\text { parameter }\end{array}$} & \multicolumn{5}{|c|}{ Models } \\
\hline & $\begin{array}{l}\text { Chemical } \\
\text { reaction }\end{array}$ & $\begin{array}{l}\text { Liquid film } \\
\text { diffusion }\end{array}$ & $\begin{array}{c}\text { Product layer } \\
\text { diffusion }\end{array}$ & Avremi & $\begin{array}{c}\text { Pseudo first } \\
\text { order }\end{array}$ \\
\hline & $\mathrm{R}^{2}$ & $\mathrm{R}^{2}$ & $\mathrm{R}^{2}$ & $\mathrm{R}^{2}$ & $\mathrm{R}^{2}$ \\
\hline \multicolumn{6}{|l|}{ Particle size } \\
\hline $0.045 \mathrm{~mm}$ & 0.731 & 0.743 & 0.980 & 0.712 & 0.667 \\
\hline $0.105 \mathrm{~mm}$ & 0.732 & 0.712 & 0.978 & 0.765 & 0.692 \\
\hline $0.25 \mathrm{~mm}$ & 0.754 & 0.739 & 0.989 & 0.743 & 0.661 \\
\hline $0.54 \mathrm{~mm}$ & 0.712 & 0.751 & 0.995 & 0.802 & 0.671 \\
\hline \multicolumn{6}{|l|}{ Acid conc. } \\
\hline $0.5 \mathrm{M}$ & 0.732 & 0.773 & 0.997 & 0.773 & 0.661 \\
\hline $1.5 \mathrm{M}$ & 0.773 & 0.743 & 0.991 & 0.743 & 0.665 \\
\hline $2 \mathrm{M}$ & 0.721 & 0.754 & 0.995 & 0.723 & 0.610 \\
\hline $3 \mathrm{M}$ & 0.743 & 0.745 & 0.976 & 0.712 & 0.623 \\
\hline \multicolumn{6}{|l|}{$\begin{array}{l}\text { Liquid-solid } \\
\text { ratio }\end{array}$} \\
\hline $4 \mathrm{~cm}^{3} / \mathrm{g}$ & 0.754 & 0.735 & 0.993 & 0.763 & 0.637 \\
\hline $8 \mathrm{~cm}^{3} / \mathrm{g}$ & 0.755 & 0.755 & 0.978 & 0.791 & 0.674 \\
\hline $10 \mathrm{~cm}^{3} / \mathrm{g}$ & 0.720 & 0.762 & 0.993 & 0.788 & 0.661 \\
\hline $16 \mathrm{~cm}^{3} / \mathrm{g}$ & 0.714 & 0.776 & 0.967 & 0.712 & 0.664 \\
\hline \multicolumn{6}{|l|}{ Stirring speed } \\
\hline 90rpm & 0.722 & 0.745 & 0.983 & 0.773 & 0.647 \\
\hline 320rpm & 0.751 & 0.765 & 0.994 & 0.771 & 0.674 \\
\hline 540rpm & 0.721 & 0.772 & 0.990 & 0.781 & 0.674 \\
\hline 720rpm & 0.734 & 0.776 & 0.985 & 0.703 & 0.664 \\
\hline \multicolumn{6}{|l|}{$\begin{array}{l}\text { Leaching } \\
\text { temperature }\end{array}$} \\
\hline $45^{\circ} \mathrm{C}$ & 0.732 & 0.765 & 0.995 & 0.776 & 0.723 \\
\hline $65^{\circ} \mathrm{C}$ & 0.741 & 0.745 & 0.985 & 0.774 & 0.662 \\
\hline $85^{\circ} \mathrm{C}$ & 0.721 & 0.872 & 0.993 & 0.732 & 0.634 \\
\hline
\end{tabular}

In order to determine the reaction order, the plot of the natural logarithm of the apparent rate constants against the natural logarithm of each process variable was obtained from the relation in Equation (8) and the plots were presented in Figures 14.0 through 18.0

$\ln (-r)=\ln K+n \ln C_{A}$

A semi-empirical model was developed from the analysis given in Equation (9) as

$1+2(1-\mathrm{X})-3(1-\mathrm{X})^{\frac{2}{3}}=\mathrm{AC}_{\mathrm{H} 2 \mathrm{SO} 4}^{\mathrm{a}} \mathrm{D}^{\mathrm{b}}(\mathrm{L})^{\mathrm{c}} \mathrm{S}^{\mathrm{d}} \exp \left(\frac{-\mathrm{E}_{\mathrm{a}}}{\mathrm{RT}}\right) \mathrm{t}$

Where,

The variables a,b,c,d were determined from the slopes of the plots (Figures 14, 15, 16, and 17) as 0.608, $0.5937,1.19$ and 0.6409 respectively while the values of $A$ and $E_{a}$ were obtained as order and slopes respectively from (Figure 18). A was obtained as 0.0008697 and $E$ was $38.88 \mathrm{KJ} / \mathrm{Mol}$. Substituting these values into Equation (9), the dissolution of iron in Ozoro clay in $\mathrm{H}_{2} \mathrm{SO}_{4}$ could be described by the following equation 


$$
1+2(1-\mathrm{X})-3(1-\mathrm{X})^{\frac{2}{3}}=0.0008697 \mathrm{C}_{\mathrm{H} 2 \mathrm{SO} 4}^{0.608} \mathrm{D}^{-0.5937}(\mathrm{~L})^{1.19} \mathrm{~S}^{0.6409} \exp \left(\frac{-38.88}{\mathrm{RT}}\right) \mathrm{t}
$$

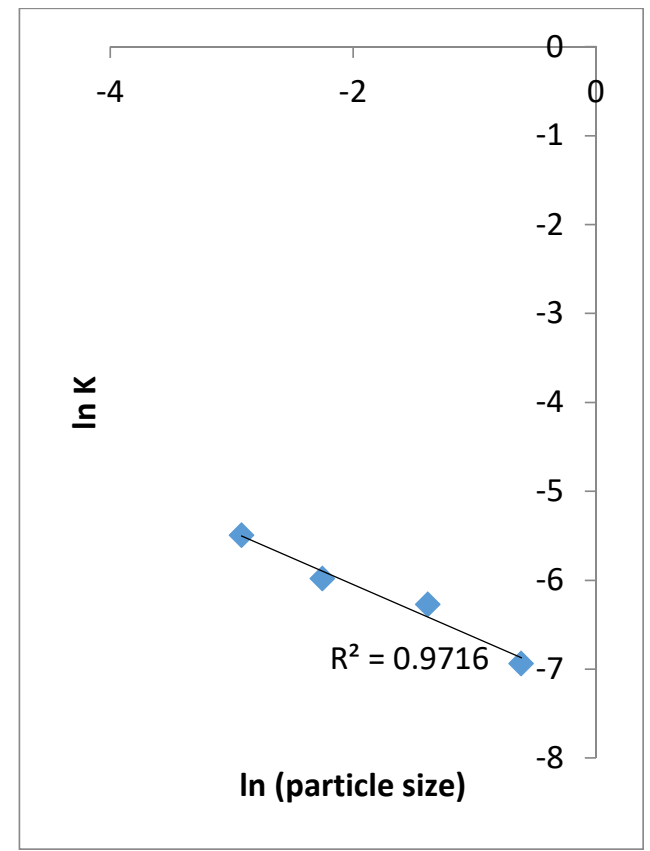

Figure 14.0: Plot of In K Vs In (part. Size) for iron with $\mathrm{H}_{2} \mathrm{SO}_{4}$

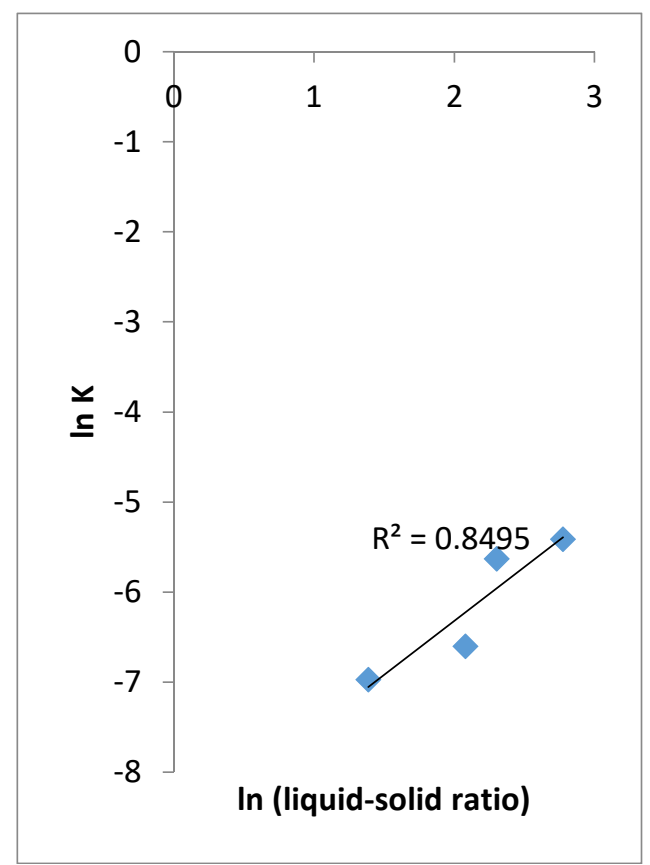

Figure 16.0: Plot of $\ln K$ Vs In (liquid-solid ratio) for iron with

$\mathrm{H}_{2} \mathrm{SO}_{4}$

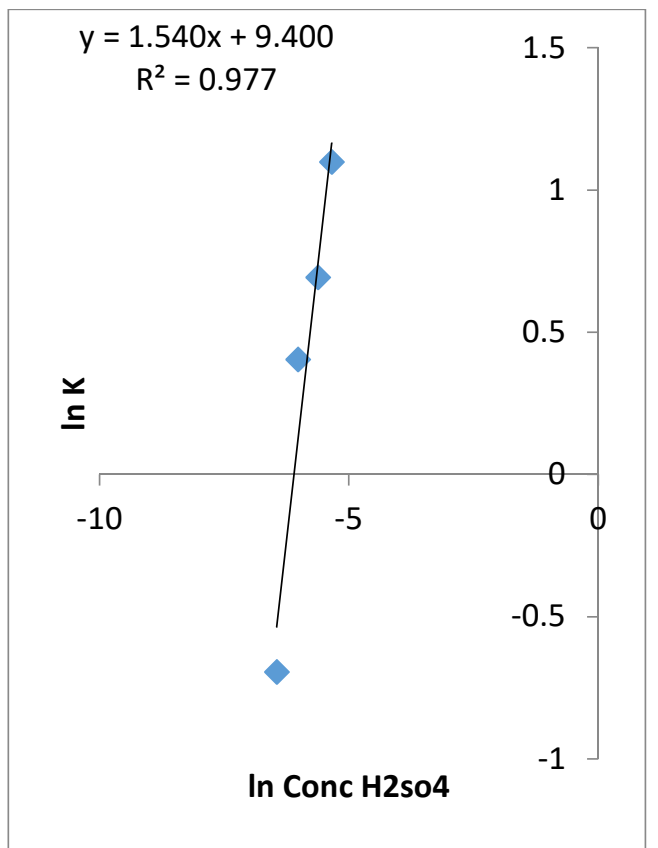

Figure 15.0: Plot of $\ln \mathrm{K}$ Vs $\ln$ $\left(\mathrm{H}_{2} \mathrm{SO}_{4}\right.$ Conc) for iron

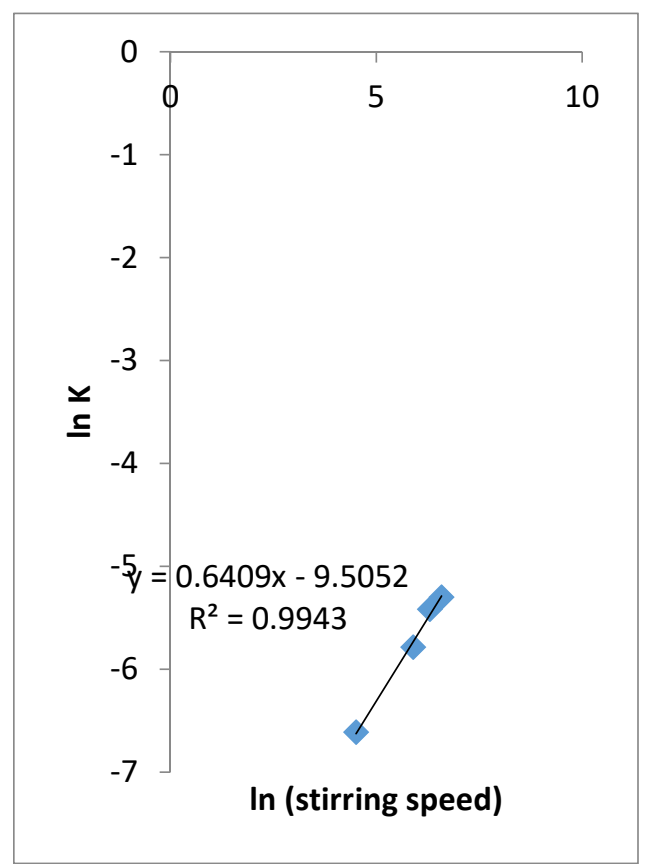

Figure 17.0: Plot of $\ln K$ Vs ln (stirring speed) for iron with $\mathrm{H}_{2} \mathrm{SO}_{4}$ 


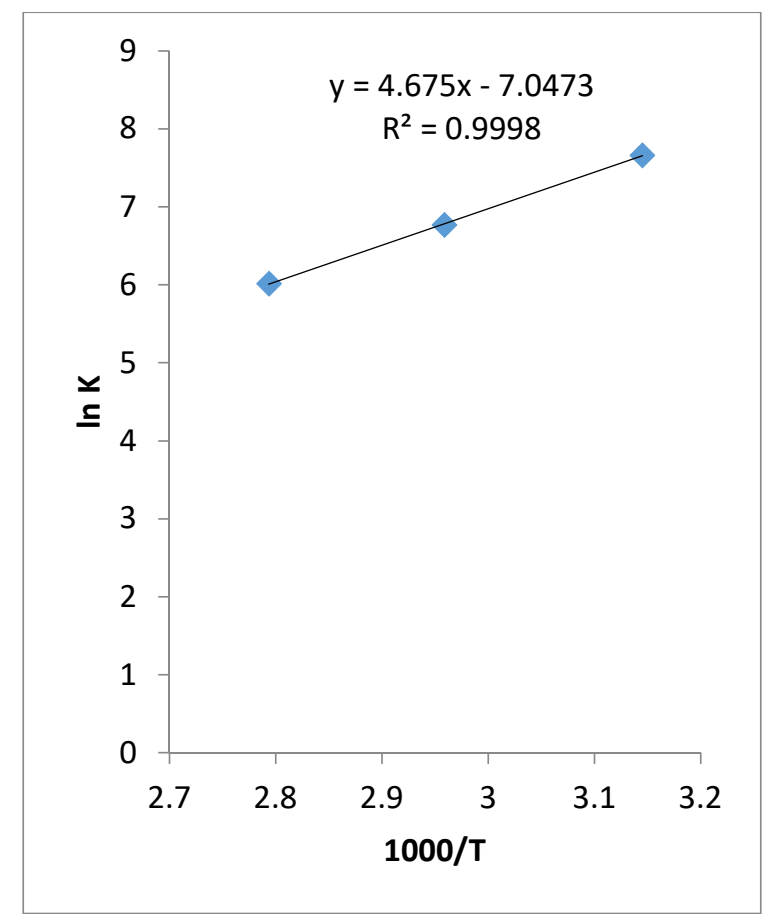

Figure 18.0: Plot of ln K Vs ln 1000/T for iron with $\mathrm{H}_{2} \mathrm{SO}_{4}$

\section{CONCLUSION}

The kinetics of iron leaching from Ozoro clay which is a viable source of iron has been studied in this research. Temperature and time has been found to be very important factors influencing the thermal activation of the local clay with the highest yield at $800^{\circ} \mathrm{C}$ at $1 \mathrm{hr}$. Increasing all the process variables increased the yield of iron oxide with the exception of particle size. The dissolution of the local clay followed the product layer diffusion model and the apparent activation energy was calculated as $38.88 \mathrm{KJ} / \mathrm{Mol}$. 


\section{REFERENCE}

1. Ajemba, R.O., Onukwuli, O.D., 2012. Kinetic Model for Ukpor Clay Dissolution in Hydrochloric Acid Solution. Journal of Emerging Trends in Engineering and Applied Sciences, 3 (3), 448-454.

2. Alafara, A., Adekola, F., Folashade, A., 2005. Quantitative Leaching of a Nigerian Iron Ore in Hydrochloric Acid. Journal of Applied Science and Environmental Management, 9,15-20

3. Ambikadevi, V., Lalithambika, M., 2000. Effects of Organic Acids on Ferric Iron Removal from Ironstained Kaolinite. Applied Clay Science, 16, 133-145.

4. Chiarizia, E., Horwitz, P., 1991. New formulations for Iron Oxides Dissolution. Hydrometallurgy, 27, 339-360.

5. Levenspiel, O., 1999. Chemical Reaction Engineering, Third edition, John Wiley \& Sons,

6. New York.

7. Lori, A., Lawal, O., Ekanem, E., 2007. Characterization and Optimisation of Deferration of Kankara Clay. ARPN Journal of Engineering and Applied Sciences, 2, 60-72.

8. Ogbemudia, J., Felix, O., Uzoma, N., 2010. Characterization of Ugbegun Clay deposit for its potential. International Journal of Chemistry Research, 1(2), 22-23.

9. Ogbuagu, J., Asuzu, A., Igbokwe, P., 2007. Characterization and Utilization of Kaolin Mineral Deposits in Ukpor Anambra State Nigeria. Nigerian Journal of Environmental Research Developement, 6(2).

10. Orugba, O.H., Onukwuli, O.D., Njoku, N.C., Ojebah, C.K., Nnanwube, I.A., 2014. Process Modeling of Sulphuric Acid Leaching of Iron from Ozoro Clay. European Scientific Journal, 10(30), 256-268.

11. Panias, D., Taxiarchou M., Paspaliaris, I., Kontopoulos, A., 1999. Mechanisms of dissolution of Iron Oxides in aqueous Oxalic Acid solution. Hydrometallurgy, $42,257-265$.

12. Sultana, U.K., Fahmida G., and Kurny, A.S., 2014. Kinetics of Leaching of Iron Oxide in Clay in Oxalic Acid and in Hydrochloric Acid Solutions. Materials Science and Metallurgy Engineering, 2(1), 5-10.

13. Sung, O. L., Tam, T., Byoung, H., Seong, J.K., Myong, J.K., 2007. Dissolution of Iron oxide using Oxalic Acid. Hydrometallurgy, 87, 91-99.

14. Suong, O.L., Tam, T., Yi Yong, P., Seong, J.K., Myong, J.K., 2006. Study on the Kinetics of Iron Oxide Leaching by Oxalic Acid, International Journal of Miner Process, 80, 144-152.

15. Vicente M. A., Barrios, M. S., Lopez-Gonzalez, J. D., Banares-Munoz, M. A., 1994. Acid Activation of a Ferrous Saponite (griffithite): Physico-Chemical Characterization and Surface Area of the products obtained. Clays and clay Minerals, 42,724 -730. 


\section{APPENDIX}

$\mathrm{x}=$ fraction extracted,

$\mathrm{K}=$ rate constant

$\mathrm{t}=$ time

$X=$ fraction of alumina extracted

$\mathrm{C}=$ acid concentration

$\mathrm{D}=$ diameter of particle

$\mathrm{L}=$ liquid-solid ratio

$\mathrm{S}=$ stirring speed

$E_{a}=$ activation energy

$A=$ collision frequency

$\mathrm{R}=$ universal gas constant

$\mathrm{t}=$ time

$a=$ reaction order for acid concentration variation

$b=$ reaction order for particle size variation

$\mathrm{c}=$ reaction order for liquid-solid ratio variation

$\mathrm{d}=$ reaction order for stirring speed variation 